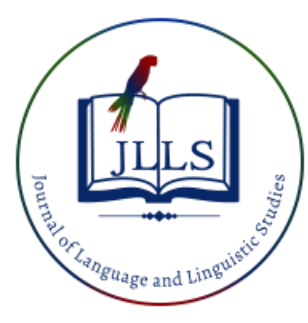

Available online at www.jlls.org

JOURNAL OF LANGUAGE

AND LINGUISTIC STUDIES

ISSN: $1305-578 \mathrm{X}$

Journal of Language and Linguistic Studies, 17(1), 225-238; 2021

\title{
A survey into the publications of faculty members in Arabic language education
}

\section{departments}

\author{
Gürkan Dağbaşı a 1 iD \\ ${ }^{a}$ School of Foreign Languages, Ankara Hacı Bayram Veli University, Ankara, Turkey
}

\section{APA Citation:}

Dağbaşı, G. (2021). A survey into the publications of faculty members in Arabic language education departments. Journal of Language and Linguistic Studies, 17(1), 225-238. Doi: 10.52462/jlls.13

Submission Date: 04/01/2021

Acceptance Date: 15/03/2021

\begin{abstract}
Since 2010, other Arabic Language Education Departments have been founded to train Arabic language teachers at both state and foundation universities. As of 2020-2021, a total of eight universities are actively training Arabic language teachers. Although teaching is considered a fundamental duty of academics, making academic publications is as important as giving lectures in the context of contributing to the home country and the world literature. This study aims to provide a survey into the publications of the permanent academic staff of eight active Arabic Language Education Departments in Turkey in terms of several aspects such as quantity, type of publication, distribution by a person, or a relation between the academics BA major and their publications. The results of the study reveal that the academics working at Arabic Language Education Departments published mainly literature-related academic works even though they worked at education faculties. It was found that the publications in the field of education constituted only one-fifth of the total number of academic publications. Another result is that the number of publications on theology, which are not related to Arabic education, is almost equal to educational publications in number.
\end{abstract}

Keywords: teacher training; Arabic; Arabic language education; academic publications; language teaching

\section{Introduction}

The conditions in the world are always changing. This change requires individuals to constantly renew themselves and adapt to new conditions. The most important role in ensuring this falls to teacher education (Irgatoğlu, 2018).

It is the teachers who, throughout the history of humanity, have played a pioneering role as one of the cornerstones of education by aiding the transfer of social values to future generations, by acting as a bridge between those who demand knowledge and those who have it, and by helping the individuals to keep up with technological and social changes taking place around them. (MEB, 2017: 1; Irgatoğlu, 2018)

In any educational system, there is a direct correlation between the quality of education and the quality of teachers. Therefore, it is imperative to provide a qualified education to the teachers in the process from their training to their selection, from hiring to preparing them for different situations they

\footnotetext{
${ }^{1}$ Corresponding author.

E-mail address: gurkan.dagbasi@hbv.edu.tr
} 
may encounter in the classroom. Likewise, academics who train teachers in higher education, since they are also instructor trainers, need to be supported throughout their academic life and to be encouraged to develop themselves, contribute to universal science, and do conduct research.

As the Ministry of National Education (MEB), in the framework of its General Competencies for Teaching Profession (MEB, 2017: 8), specifies it as a competence that teachers need 'have an advanced and critical perspective on theoretical, methodological and factual knowledge in his/her subject field,' it would be ill-advised not to expect the same from academics who train these teachers. One of the basic ways for a faculty member to achieve this competence is through reading recent publications in his field, contributing his own knowledge and experience to them, and then publishing new academic work in order to increase knowledge in the field.

Demirel (1991: 25) states that foreign language education in Turkey starts with Arabic language teaching in elementary schools and madrasas in the Ottoman Empire period and that the army personnel was taught French starting with the Tanzimat period. Akyüz (2006: 18) maintains that teacher training and teaching as a profession in their contemporary sense began to appear and take shape in Turkey after 1848. Yet, Gömleksiz (1999: 81) defines this date as the 1930s. Gömleksiz (1999) states that, in 1935, there were two hundred and fifty French, seventy-one English, and fortyone German language teachers who were working in Turkey. However, there is no information regarding the number of Arabic language teachers at that time. The probable reason for this is that Arabic was considered to be a part of theology rather than a foreign language. In fact, this is still largely the case today.

When we consider the training of Arabic language teachers in the context of religious education, the years 1933-1949 were gap years, and the years 1949-1971 were the years when higher religious education institutions were founded and when their graduates started working as teachers in their own field (Ev, 2011; Özcan, 2015).

After the Higher Education Law No. 2547 was enacted in 1981, all higher education institutions in our country were gathered under the umbrella of the Council of Higher Education (YÖK), and the then-called Education Institutes, which were institutions for teacher training, were transformed into Education Faculties. The departments and programs of these faculties of education that were now gathered under a single administrative center were varied in accordance with the needs of the period. Besides, as stated by Akdemir (2013: 19), teacher training programs have been renewed from time to time since, on the grounds that they were behind their age.

\subsection{Research questions}

The purpose of this study is to examine the publications of faculty members working at Departments of Arabic Language Education at eight state and foundation universities in Turkey which actively enroll students and train Arabic language teachers, in terms of publication type and quantity in order to reach conclusions about the attitude of the academics, to make some future suggestions (Abdul, 2020).

The research questions of the study are:

1- What are the BA majors of the faculty members working at the Departments of Arabic Language Education?

2- What are the numbers of publications of faculty members in the Departments of Arabic Language Education for each university and each academic?

3- Which Department of Arabic Language Education stands out quantitatively in the terms of published books/book chapters, articles, and presented papers? 
4- Which Departments of Arabic Language Education publish more in which field of study (education, literature, translation and interpreting studies, and theology)?

5- What is the distribution of the number and types of publications in Turkey in general?

6- Is there a significant difference between public and foundation universities regarding the number of publications?

7- What is the number of the publications on education by academics who work in the Arabic Language Education Departments of Education Faculties?

\section{Method}

This study employs a qualitative method.

\subsection{Participants}

Within the scope of the research, the publications of fifteen academics at four state universities and sixteen academics at four foundation universities were accessed by browsing both their personal pages and the Academic Search page of the Council of Higher Education.

\subsection{Instrument}

All the publications of the academics in this field have been accessed on the internet.

\subsection{Data analysis}

The data obtained from academic publications were classified with the help of a statistician, and the interpretations were made on these statistical data.

\subsubsection{An Overview of Arabic Language Teaching and Its Statue in Higher Education in Turkey}

The relations between Turks and Arabs go centuries back and they continued to improve after Turks embraced Islam. As a result of these intense and long relations, Arabic, especially for being the language of religious texts, has always been a part of our education system from madrasahs, primary schools, secondary schools to teacher-training schools [dâru'l-muallimîn / muallimat] which we can consider our oldest educational institutions. Arabic, which was first taught in Religious Vocational high and secondary schools, which were first opened in 1924, then closed in 1931 and reopened in 1951, and in Islamic Institutes, is now taught as a compulsory course in Religious Vocational high and secondary schools and as an elective foreign language course in other primaries, secondary and high schools. According to the statistics of MEB (2019: 214), approximately one million four hundred thousand students are interested in and/or learn Arabic. Besides, every year approximately twenty-five thousand students enroll in the departments of Arabic Language Education, Arabic Language and Literature, Arabic Translation and Interpretation, and the Faculty of Theology at universities. Arabic is taught in the Land Forces Command Language School, Military Academies, and many private courses. According to OSYM 2019 data, Arabic is the second most preferred language after English in foreign language exams.

Despite such a deep and long history of Arabic language learning and almost one and a half million learners, the number of departments that train teachers to teach Arabic as a foreign language is currently only eight. The first department to train Arabic language teachers was established at Gazi University in 1984, and this university remained the only one in its field until 2010. In the following years, other departments of Arabic Language Education opened started to train Arabic language teachers at Adıyaman, Süleyman Demirel, and Necmettin Erbakan Universities, which are all state 
universities. Foundation universities such as Istanbul Aydın, Istanbul Sebahattin Zaim, Fatih Sultan Mehmet Foundation, and Istanbul 29 Mayis Universities have also established this department and started to enroll students in the last five years. Apart from these eight universities, other universities have a Department of Arabic Language, but these universities are not included in this study since they have not started accepting students yet.

Among the basic missions of universities are to publish studies by doing scientific research, to broaden and disseminate information for those who are concerned, as well as to train students who are equipped with the knowledge required by the era. Demirel (1991: 34) states that there are not enough research and original studies in the field of foreign language teaching at faculties of education. Although it has been thirty years since Demirel's study, there is almost no research examining the publications of the academics working in the field of foreign language teaching in terms of quantity or quality. The main purpose of this study is to examine the publications of faculty members working in the field of Arabic Language Education from various aspects, to make inferences about their publishing attitudes, and to present quantitative data on their publications. The fact that this type of research has not been done before is another outstanding feature of the study.

\section{Results and Discussion}

The characteristics of faculty members are shown in Table 1.

Table 1. Number of faculty members working in the field of Arabic language education

\begin{tabular}{lcccc}
\hline \multicolumn{1}{c}{ University } & Professor & $\begin{array}{c}\text { Associate } \\
\text { Professor }\end{array}$ & Assistant Professor & $\begin{array}{c}\text { Total Number } \\
\text { of Faculty } \\
\text { Members }\end{array}$ \\
\hline Gazi University & 2 & 4 & - & 6 \\
Adiyaman University & - & - & 3 & 3 \\
Necmettin Erbakan University & - & - & 3 & 3 \\
Süleyman Demirel University & 1 & - & 2 & 3 \\
İstanbul Sebahattin Zaim University & - & - & 4 & 4 \\
İstanbul Aydın University & 3 & - & 3 & 6 \\
Fatih Sultan Mehmet Foundation & 1 & - & 2 & 3 \\
University & 1 & 1 & 1 & 31 \\
İstanbul 29 Mayis University & 8 & 5 & 18 & \\
Total number of Faculty Members & & &
\end{tabular}

In Turkey, the total number of faculty members at the eight Departments of Arabic Language Education is 31; it means there are 3,87 members per department. Five of these departments provide education with only three academics, which is the required minimum for a department in order to be able to enroll students. Probably, the course load of the faculty members in these departments is high, and hence their productivity decreases. In the other three departments, there are no professors and associate professors that we can describe as 'experienced' academics. This is obviously a drawback. It is observed that education in the Departments of Arabic Language Education is mostly carried out by assistant professors. In this respect, it is crucial to increase the number of faculty members as well as the number of associate professors and professors in order to increase the quality of education. 
Table 2. BA major of faculty members working in the field of Arabic language education

\begin{tabular}{lccc}
\hline \multicolumn{1}{c}{ University } & $\begin{array}{c}\text { Faculty of } \\
\text { Education }\end{array}$ & $\begin{array}{c}\text { Faculty of Arts and } \\
\text { Sciences }\end{array}$ & $\begin{array}{c}\text { Faculty of } \\
\text { Theology }\end{array}$ \\
\hline Gazi University & 4 & 2 & - \\
Adıyaman University & - & - & 3 \\
Necmettin Erbakan University & - & - & 3 \\
Süleyman Demirel University & 3 & - & - \\
İstanbul Sebahattin Zaim University & 2 & 5 & 1 \\
İstanbul Aydın University & - & 2 & 1 \\
Fatih Sultan Mehmet Foundation University & 1 & 2 & - \\
İstanbul 29 Mayis University & - & 12 & 1 \\
Total number of Faculty Members & 10 & & 9 \\
\hline
\end{tabular}

Most of the faculty members working at departments of Arabic Language Education are graduates of faculties of arts and sciences, which is interesting. It is a grave concern that there are no faculty members who are graduates of faculties of education at Adiyaman, Necmettin Erbakan, Istanbul Aydın, and Istanbul 29 Mayıs Universities. It is also surprising that the Council of Higher Education allows these universities to enroll students even though they do not have faculty members who are graduates of education faculties. It may be interpreted that it is academics who have not taken any pedagogic proficiency courses and who do not proficiently know how to teach Arabic as a foreign language that are training Arabic language teachers in faculties of education at the moment. In addition, all of the faculty members at the Department of Arabic Language Education at Necmettin Erbakan and Adiyaman University are graduates of the faculty of theology. This shows us that the Arabic language, despite being the source language of our great religion, still is not considered a foreign language in Turkey. However, theology education and Arabic Language Education are very different subjects. Finally, it can be said that the fact that the Ph.D. program in Arabic Language Education is provided only at Gazi University also has its role in this result.

Table 3. Types and number of works published by Arabic language education faculty members

\begin{tabular}{cccccc}
\hline University & $\begin{array}{c}\text { Book/ } \\
\text { Book Chapter }\end{array}$ & Article & $\begin{array}{c}\text { Paper } \\
\text { Presen- } \\
\text { tation }\end{array}$ & Total & $\begin{array}{c}\text { Ratio to all } \\
\text { publications }\end{array}$ \\
\hline Gazi University & 125 & 99 & 96 & 320 & $\% 40,40$ \\
Adiyaman University & 11 & 56 & 31 & 98 & $\% 12,37$ \\
Necmettin Erbakan University & 6 & 6 & 7 & 19 & $\% 2,39$ \\
Süleyman Demirel University & 6 & 24 & 13 & 43 & $\% 5,42$ \\
İstanbul Sebahattin Zaim & 6 & 9 & 11 & 26 & $\% 3,28$ \\
$\quad$ University & 41 & 39 & 18 & 98 & $\% 12,37$ \\
İstanbul Aydın University & 19 & 55 & 32 & 106 & $\% 13,38$ \\
Fatih Sultan Mehmet Foundation & & & & & $\% 10,35$ \\
University & 30 & 35 & 17 & 82 & - \\
İstanbul 29 Mayis University & 244 & 323 & 225 & 792 & \\
Total number of the publications & & & &
\end{tabular}


The total number of publications of faculty members working at the departments of Arabic Language Education is 792. Academics at these departments published mostly articles, books/book chapters, and papers in this given order. Gazi University Arabic Language Education Department has unproportionally more publications with a rate of $40,40 \%$. The Department of Arabic Language Education at Gazi University is the first program established to train Arabic language teachers in 1984 in Turkey and also had been the only one for quite many years. It would not be wrong to say that having been founded many years ago at a well-established university and having good staff is one of the factors that ensures this high number of publications. The publication rates of Adiyaman, Fatih Sultan Mehmet Foundation, and Istanbul Aydın Universities are very close to each other. Istanbul 29 Mayıs, Süleyman Demirel, Istanbul Sebahattin Zaim and Necmettin Erbakan universities follow these universities.

Table 4. Number of publications (book/book chapter-article-paper presentation) per faculty member of Arabic language education at each university

\begin{tabular}{ll}
\hline University & Number of publications \\
\hline Gazi University & 53,3 \\
Adiyaman University & 32,6 \\
Necmettin Erbakan University & 6,33 \\
Süleyman Demirel University & 14,13 \\
İstanbul Sebahattin Zaim University & 6,5 \\
İstanbul Aydın University & 16,3 \\
Fatih Sultan Mehmet Foundation University & 18 \\
İstanbul 29 Mayıs University & 28 \\
Publication average of universities & 25,54 \\
\hline
\end{tabular}

Among the universities which have the Department of Arabic Language Education, Gazi University is in the first place with 53,3 publications per faculty member, a bit more than twice the average of publications in Turkey. Adiyaman and İstanbul 29 Mayıs Universities are two other prominent universities. Necmettin Erbakan and Istanbul Sebahattin Zaim Universities are the weakest universities in this field. By examining the data in this section, it can be stated that academics at some universities systematically and regularly publish books, book chapters, articles, and present papers in scientific conventions; and that some academics are not able to achieve this. It would be an optimistic wish to assume and expect that the experience of the academics will broaden and their course load will decrease with new faculty member hires and they will thereby increase their publication average. Besides, determining the minimum publication requirements within reasonable limits on an anual basis may contribute to an increase in the quantity.

Table 5. University performance according to the number of books/book chapters

\begin{tabular}{lccc}
\hline University & $\begin{array}{c}\text { Number of } \\
\text { Publications }\end{array}$ & $\begin{array}{c}\text { Ratio to Book/ Book } \\
\text { Chapter } \\
\text { Publications in } \\
\text { General }\end{array}$ & $\begin{array}{c}\text { Number of } \\
\text { Publication } \\
\text { Per Faculty } \\
\text { Member }\end{array}$ \\
\hline Gazi University & 125 & $\% 51,22$ & 20,18 \\
Adiyaman University & 11 & $\% 4,5$ & 3,66 \\
Necmettin Erbakan University & 6 & $\% 2,45$ & 3 \\
\hline
\end{tabular}




\begin{tabular}{lccc}
\hline Süleyman Demirel University & 6 & $\% 2,45$ & 2 \\
İstanbul Sebahattin Zaim University & 6 & $\% 2,45$ & 1,5 \\
İstanbul Aydın University & 41 & $\% 16,8$ & 6,83 \\
Fatih Sultan Mehmet Foundation University & 19 & $\% 7,78$ & 6,33 \\
İstanbul 29 Mayıs University & 30 & $\% 12,29$ & 10 \\
Average number of books/book chapters in & 244 & - & 7,87 \\
Turkey & & & \\
\hline
\end{tabular}

Just as it was with the number of overall publications, Gazi University faculty members are again in the first place in the book/book chapter criteria both in terms of the number of publications and of the number of general publications per faculty member. Gazi University faculty members have published more books/book chapters than the academics of all other universities. All other universities in Turkey are below the average of 7,87. Istanbul Aydin and Istanbul 29 Mayis Universities are in the second and third place respectively. Necmettin Erbakan, Süleyman Demirel and Istanbul Sebahattin Zaim Universities have quite a low number of book/book chapter publications.

Table 6. University performance according to the number of articles published

\begin{tabular}{lccc}
\hline \multicolumn{1}{c}{ University } & $\begin{array}{c}\text { Number of } \\
\text { Publications }\end{array}$ & $\begin{array}{c}\text { Ratio to Article } \\
\text { Publications in } \\
\text { General }\end{array}$ & $\begin{array}{c}\text { Number of } \\
\text { Publications } \\
\text { Per Faculty } \\
\text { Member }\end{array}$ \\
\hline Gazi University & 99 & $\% 30,65$ & 16,5 \\
Adıyaman University & 56 & $\% 17,33$ & 18,6 \\
Necmettin Erbakan University & 6 & $\% 1,85$ & 2 \\
Süleyman Demirel University & 24 & $\% 7,43$ & 8 \\
İstanbul Sebahattin Zaim University & 9 & $\% 2,78$ & 2,25 \\
İstanbul Aydın University & 39 & $\% 12,07$ & 6,5 \\
Fatih Sultan Mehmet Foundation University & 55 & $\% 17,02$ & 18,33 \\
İstanbul 29 Mayıs University & 35 & $\% 10,83$ & 11,6 \\
Number, ratio, and average of articles in Turkey & 323 & - & 10,41 \\
\hline
\end{tabular}

Regarding the number of articles, Gazi University ranks first, but in terms of articles published per faculty member, Adiyaman University is in the first place, followed by Fatih Sultan Mehmet Foundation University with a close number of articles. Istanbul 29 Mays University faculty members have published more articles than the average in Turkey. Especially at Necmettin Erbakan and Istanbul Sebahattin Zaim Universities, both the total number of articles and the number of articles per academic staff are very low. One of the reasons for the low number of article publications may be that all of the faculty members working at these two universities have little academic experience and have just completed their Ph.D. 
Table 7. University performance according to the number of papers presented

\begin{tabular}{lccc}
\hline \multicolumn{1}{c}{ University } & $\begin{array}{c}\text { Number of } \\
\text { Papers }\end{array}$ & $\begin{array}{c}\text { Ratio to Paper } \\
\text { Presentations in } \\
\text { General }\end{array}$ & $\begin{array}{c}\text { Number of } \\
\text { Papers Per } \\
\text { Faculty } \\
\text { Member }\end{array}$ \\
\hline Gazi University & & $\% 42,66$ & 16 \\
Adiyaman University & 96 & $\% 13,7$ & 10,33 \\
Necmettin Erbakan University & 31 & $\% 3,11$ & 2,33 \\
Süleyman Demirel University & 7 & $\% 5,77$ & 4,33 \\
İstanbul Sebahattin Zaim University & 13 & $\% 4,88$ & 2,75 \\
İstanbul Aydin University & 11 & $\% 8$ & 3 \\
Fatih Sultan Mehmet Foundation University & 18 & $\% 14,22$ & 10,66 \\
İstanbul 29 Mayis University & 32 & $\% 7,55$ & 5,66 \\
Number, ratio, and average of papers in Turkey & 17 & - & 8,22 \\
\hline
\end{tabular}

It cannot be denied that attending congresses, symposiums, presenting papers, and having the opportunity to listen to dozens of other scientific presentations in a few days, whether national or international, are important for the development of academics. In this respect, Gazi University is clearly ahead in the paper presentation category. Fatih Sultan Mehmet Foundation and Adiyaman Universities took second and third place, faculty members of these two universities have presented more papers than the average in Turkey. The number of papers presented by the faculty members of the other five universities is below the average. Encouraging the participation of faculty members in scientific activities at universities where there are two or three papers per faculty member will directly contribute to their development and therefore it will indirectly contribute to the development of the students studying at these departments.

Table 8. Number and type of works published in state-foundation universities

\begin{tabular}{lcccc}
\hline \multicolumn{1}{c}{ University } & Book/ Book Chapter & Article & Paper & Total \\
\hline State Universities & 143 & 185 & 147 & 480 \\
Foundation Universities & 96 & 138 & 78 & 312 \\
\hline
\end{tabular}

When the number of publications is examined according to state-foundation universities, it is seen that state universities are ahead in each publication type with a total of 480 publications $(60,60 \%)$. Foundation universities have a total of 321 publications $(39,40 \%)$. While there are 32 publications per academic at state universities, this number is 19,5 per academic at foundation universities. It is appreciated that foundation universities have started Departments of Arabic Language Education and have contributed to publications in this field.

Table 9. Subject areas of works published by faculty members of Arabic language education

\begin{tabular}{lcccc}
\hline \multicolumn{1}{c}{ University } & Education & Literature & $\begin{array}{c}\text { Translation and } \\
\text { Interpreting } \\
\text { Studies }\end{array}$ & Theology \\
\hline Gazi University & 66 & 217 & 33 & 4 \\
Adiyaman University & 4 & 8 & - & 86 \\
\hline
\end{tabular}




\begin{tabular}{lcccc}
\hline Necmettin Erbakan University & 9 & 9 & - & 1 \\
Süleyman Demirel University & 19 & 22 & 2 & - \\
İstanbul Sebahattin Zaim University & 14 & 9 & - & 3 \\
İstanbul Aydın University & 15 & 64 & - & 29 \\
Fatih Sultan Mehmet Foundation University & 18 & 88 & - & - \\
İstanbul 29 Mayıs University & 28 & 13 & 1 & 40 \\
Total & 173 & 430 & 36 & 163 \\
\hline
\end{tabular}

It is possible to regard the publications of the Department of Arabic Language Education within four basic categories. These categories are given in table 9. It is expected that the publications on education should be well ahead; however, when we look at the data, the number of publications related to education constitutes only $21,84 \%$ of the total publications and this rate is far less than ideal. The rate of literature-related publications is in the first place with a rate of $54,29 \%$. That most of the faculty members working at the Department of Arabic Language Education are graduates of the faculty of arts and sciences can be taken as the main reason for this result. In addition, it is possible to say that faculty members who are graduates of faculty of education also publish mostly in the field of literature. The rate of studies on theology almost equals the number of publications in the field of education with a rate of $20.58 \%$. Surprisingly, there are so many publications in the field of theology in a teacher training department. It also shows that faculty members who are graduates of the faculty of theology do not prefer to publish works on education, even though they work at the departments of Arabic Language Education or cannot adapt to educational analysis. Translation and interpreting studies, on the other hand, is the field with the least publication with a rate of $4,54 \%$.

Table 10. Subject areas of published works at state-foundation universities

\begin{tabular}{lcccc}
\hline \multicolumn{1}{c}{ University } & Education & Literature & $\begin{array}{c}\text { Translation and } \\
\text { Interpreting Studies }\end{array}$ & Theology \\
\hline State Universities & 98 & 256 & 35 & 91 \\
Foundation Universities & 75 & 174 & 1 & 72 \\
\hline
\end{tabular}

Comparing the state and foundation universities, it is observed that they have similar results. Most publications have been in literature, education, theology, and translation and interpreting studies respectively at both state and foundation universities. The number of publications on education at both state and foundation universities is low. Faculty members should be encouraged and supported to produce more publications in this field.

Table 11. University performance according to publications on education

\begin{tabular}{lccc}
\hline \multicolumn{1}{c}{ University } & $\begin{array}{c}\text { Number of } \\
\text { Publications }\end{array}$ & $\begin{array}{c}\text { Ratio to Publications on } \\
\text { Education in General }\end{array}$ & $\begin{array}{c}\text { Number of } \\
\text { Publications Per } \\
\text { Faculty Member }\end{array}$ \\
\hline Gazi University & 66 & $\% 38,15$ & 11 \\
Adiyaman University & 4 & $\% 2,31$ & 1,3 \\
Necmettin Erbakan University & 9 & $\% 5,20$ & 3 \\
Süleyman Demirel University & 19 & $\% 10,98$ & 6,3 \\
İstanbul Sebahattin Zaim University & 14 & $\% 8,09$ & 3,5 \\
İstanbul Aydın University & 15 & $\% 8,67$ & 2,5 \\
\hline
\end{tabular}




\begin{tabular}{lccc}
\hline $\begin{array}{l}\text { Fatih Sultan Mehmet Foundation } \\
\text { University }\end{array}$ & 18 & $\% 10,40$ & 6 \\
$\begin{array}{l}\text { İstanbul 29 Mayis University } \\
\begin{array}{l}\text { Number, raito, and the average of } \\
\text { publications on education in Turkey }\end{array}\end{array}$ & 28 & $\% 16,18$ & 9,33 \\
\hline
\end{tabular}

Gazi University ranks first in the field of education in terms of both total publications and the number of publications per faculty member. Istanbul 29 Mayıs University is in second place and Süleyman Demirel University is in third place. And Fatih Sultan Mehmet Foundation University has published more than the average in Turkey. Adiyaman, İstanbul Aydın and Necmettin Erbakan Universities are the universities that publish the least in the field of education. The total rate of $9 \%$ of these three universities is really low and this is an intriguing result.

The average number of 5,58, which is the average number of publications on education in Turkey, must increase. In particular, it is necessary to lead and encourage faculty members with a low number of publications to carry out scientific studies in this field. Although faculty members are seen as lecturers, one of the main duties of an academic is also to produce quality publications that will contribute to his field.

Table 12. University performance according to publications on literature

\begin{tabular}{lccc}
\hline \multicolumn{1}{c}{ University } & $\begin{array}{c}\text { Number of } \\
\text { Publications }\end{array}$ & $\begin{array}{c}\text { Ratio to } \\
\text { Publications on } \\
\text { Literature in } \\
\text { General }\end{array}$ & $\begin{array}{c}\text { Number of } \\
\text { Publications Per } \\
\text { Faculty Member }\end{array}$ \\
\hline Gazi University & 217 & $\% 50,4$ & 36,1 \\
Adiyaman University & 8 & $\% 1,86$ & 2,66 \\
Necmettin Erbakan University & 9 & $\% 2,09$ & 3 \\
Süleyman Demirel University & 22 & $\% 5,11$ & 3,33 \\
İstanbul Sebahattin Zaim University & 9 & $\% 2,09$ & 10,66 \\
İstanbul Aydın University & 64 & $\% 14,88$ & 29,3 \\
Fatih Sultan Mehmet Foundation University & 88 & $\% 20,46$ & 4,33 \\
İstanbul 29 Mayis University & 13 & $\% 3,02$ & 13,8 \\
$\begin{array}{l}\text { Number, raito, and the average of publications } \\
\text { on literature in Turkey }\end{array}$ & 430 & - & 3 \\
\hline
\end{tabular}

Gazi University also takes the lead in publications on literature. Gazi University, which produces half of the publications in this field, has a very high number of 36,1 publications per faculty member. It is also striking that the faculty members of this university, who are predominantly graduates of faculty of education, publish rather on literature than education. Fatih Sultan Mehmet Foundation University is another prominent university in this field with 29,3 publications per faculty member. The numbers of publications of all other universities are below the average in Turkey. Adiyaman University, on the other hand, has the least number of publications on literature. 
Table 13. University performance according to publications on translation and interpreting studies

\begin{tabular}{cccc}
\hline University & $\begin{array}{c}\text { Number of } \\
\text { Publications }\end{array}$ & $\begin{array}{c}\text { Ratio to } \\
\text { Publications on } \\
\text { Translation and } \\
\text { Interpreting } \\
\text { Studies in General }\end{array}$ & $\begin{array}{c}\text { Number of } \\
\text { Publications } \\
\text { Perculty } \\
\text { Member }\end{array}$ \\
Gazi University & & $\% 91,66$ & 5,5 \\
Adiyaman University & 33 & - & - \\
Necmettin Erbakan University & - & - & 0,66 \\
Süleyman Demirel University & - & $\% 5,55$ & - \\
İstanbul Sebahattin Zaim University & 2 & - & - \\
İstanbul Aydin University & - & - & 0,33 \\
Fatih Sultan Mehmet Foundation University & - & 2,7 & 1,16 \\
İstanbul 29 Mayis University & 1 & $\% 4.54$ & - \\
\hline $\begin{array}{c}\text { Number, raito, and an average of publications on } \\
\text { translation and interpreting studies in Turkey }\end{array}$ & 36 & & - \\
\hline
\end{tabular}

Translation and interpreting studies are a new field in Arabic language studies. Although only three universities have publications in this field, the rate of Gazi University is 91,66\%. The reason for this high rate is that one of the faculty members at Gazi University focuses intensely on the field of translation studies.

Table 14. University performances according to publications on theology

\begin{tabular}{lccc}
\hline \multicolumn{1}{c}{ University } & $\begin{array}{c}\text { Number of } \\
\text { Publications }\end{array}$ & $\begin{array}{c}\text { Ratio to } \\
\text { Publications on } \\
\text { Theology in } \\
\text { General }\end{array}$ & $\begin{array}{c}\text { Number of } \\
\text { Publications Per } \\
\text { Faculty Member }\end{array}$ \\
\hline Gazi University & 4 & $\% 2,25$ & 0,66 \\
Adiyaman University & 86 & $\% 53,98$ & 28,66 \\
Necmettin Erbakan University & 1 & $\% 0,61$ & 0,33 \\
$\begin{array}{l}\text { Süleyman Demirel University } \\
\text { İstanbul Sebahattin Zaim University }\end{array}$ & - & - & 0,75 \\
İstanbul Aydin University & 3 & $\% 1,84$ & 4,83 \\
$\begin{array}{l}\text { Fatih Sultan Mehmet Foundation University } \\
\text { İstanbul 29 Mayis University }\end{array}$ & 29 & - & - \\
$\begin{array}{l}\text { Number, raito, and an average of publications on } \\
\text { theology in Turkey }\end{array}$ & 163 & $\% 24,53$ & 13,33 \\
\hline
\end{tabular}

Normally, it is not common to make publications in the field of theology in the departments of foreign language education. While publications on theology are very rare in the departments of English Language Education, they are very common in the departments of Arabic Language Education. The reason behind this is, as was mentioned, that almost one-third of the faculty members working at the departments of Arabic Language Education are graduates of the faculty of theology. This is reflected in the publications. Adiyaman University ranks first by making more than half of its publications in the field of theology. It is not surprising that all faculty members of the Department of Arabic 
Language Teaching at this university are graduates of the faculty of theology. Other universities that publish the most in this field are Istanbul 29 Mayıs and Istanbul Aydın universities.

"Bireysel ve Toplumsal Bağlamda Her Dönem Muhtaç Olduğumuz Özelliklerden: İtkan Erdemi; Evrimin Yedinci Günü; Kur’an’a Göre Çevre Bilinci ve Ahlakı; İsra Suresi 17/70. Ayeti Bağlamında Efdaliyet Meselesi; Gençlere Yönelik Nebevi Hitabın Özellikleri; Ceza Hukukunda Yargılama ve Şehadette Müslüman Kadının Ehliyeti”, “Qualities We Always Need in Individuals and Society: Virtue of Itkan; the Seventh Day of Evolution; Environmental Consciousness and Morality According to the Holy Quran; Virtue in the Context of Surah Isra Ayah 17/70; Features of Prophetic Speech to Young People; Judgment in Criminal Law and the Competence of a Muslim Woman in Martyrdom", are some of the publications of faculty members that are the graduates of faculty of theology who are working at the departments of Arabic Language Education. These publications are of course very valuable works in their fields, but the faculty members in these programs should focus on making publications that are suitable to the purposes of faculties of education where they work and train prospective teachers.

\section{Conclusions and Suggestions}

Today, education plays a leading role in helping the individual to adapt to the changes around him, and it equips the individual according to the needs of the age. A teacher who is well-trained in the aspects of professional knowledge, skills, attitudes, and values will undoubtedly increase the quality of education.

Although the history of teaching Arabic in our country goes centuries back, the perception of Arabic as a foreign language has not been fully maintained even today. Perhaps because of that, the first Department of Arabic Language Education was founded only in 1984 to train teachers to teach Arabic as a foreign language using modern methods and techniques, and that department remained the only one in this field until 2010. In the last ten years, seven more departments have been opened, three of which are at state universities and four at foundation universities. Arabic language teachers are actively trained in these departments.

One of the most important factors in the training of a proficient teacher is the quality of the faculty members at the university where he studies. Scientific publications are important documents showing to what extent faculty members have mastered the current developments in their fields, whether they follow scientific publications, and what they do to guide prospective teachers and to broaden their horizons.

There are a total of thirty-one faculty members in eight Arabic Language Education departments that actively enroll students in Turkey. Two-thirds of these academics are not graduates of the faculty of education. The majority is from the faculty of arts and sciences, and the rest are graduates of the faculty of theology. Besides, more than half of these academics are assistant professors.

The number of publications (books, book chapters, articles, papers) produced by faculty members of Arabic Language Education is 792 and the number of publications per faculty member is 53,3. $30,80 \%$ of these publications are books and book chapters, $40,27 \%$ are articles and $28,42 \%$ are papers.

The universities that published the greatest number of books are Gazi, Istanbul Aydın, and Istanbul 29 Mayıs Universities in order. Necmettin Erbakan, Süleyman Demirel, and Istanbul Sebahattin Zaim Universities are the ones that published the least number of books/book chapters. Although Gazi University ranks first in terms of the number of articles published, Adiyaman University is in the first place in terms of article publication number per faculty member, followed by Fatih Sultan Mehmet Foundation University. Faculty members of Istanbul 29 Mayis University have published articles above the average in Turkey. Especially in Necmettin Erbakan and Istanbul Sebahattin Zaim 
Universities, the number of articles both in total and per faculty member is very low. Gazi University ranks first in the paper category. Fatih Sultan Mehmet Foundation University and Adiyaman University rank second and third. The number of papers presented by academics of the other five universities is below the average in Turkey. In terms of the number of publications by the statefoundation universities, state universities are ahead for every type of work with a total of 480 publications $(60,60 \%)$. Foundation universities have a total of 321 publications $(39,40 \%)$.

The distribution of the works by subject area published by faculty members at departments of Arabic Language Education also reveals interesting results. The number of publications related to education constitutes $21,84 \%$ of the total publications and this rate is far less than ideal. The rate of literature-related publications is in the first place with a rate of $54,29 \%$. The reason for this may be the high number of faculty members at the Department of Arabic Language Education that are graduates of literature programs. In addition, it is possible to say those faculty members who are graduates of the faculty of education also publish a lot in the field of literature. The rate of studies on theology is almost equal to the number of publications in the field of education with a rate of $20,58 \%$. It is surprising that there are so many publications in the field of theology in a teacher-training program. And it shows that faculty members who are graduates of the faculty of theology do not prefer to publish in the field of education, even though they work at departments of Arabic Language Education or cannot focus on educational analysis. Translation and interpreting studies, on the other hand, are the field with the least number of publications with a rate of $4,54 \%$.

The universities that published the greatest number of works in the field of education are Gazi, 29 Mayıs, and Süleyman Demirel Universities in order. Adıyaman, İstanbul Aydın and Necmettin Erbakan Universities are the ones that have the least number publications on education. Gazi University, which produces half of the publications on literature, has a very high number of 36,1 publications per faculty member. Fatih Sultan Mehmet Foundation University is another prominent university in this field with 29,3 publications per faculty member. The number of publications of all other universities is below the average in Turkey. In the field of theology, Adiyaman University ranks first with more than half of the publications. All faculty members at the Department of Arabic Language Education at this university are graduates of the faculty of theology. Other universities that publish the most in this field are Istanbul 29 Mayıs and Istanbul Aydın Universities.

The average number of publications on education in Turkey per faculty member is 5,58, and it should increase. Faculty members should be encouraged to publish studies especially on the subject of Arabic Language Education, which is their profession. The Arabic Language Education Ph.D. program, which is currently only available at Gazi University, should be started at other universities as well. The number of academics with a doctoral degree in this field should be increased and those who graduate from these programs should be hired as lecturers at departments that train Arabic language teachers. New departments of Arabic Language Education should also be opened in a measured manner. Students should not be admitted if no faculty member graduated from the faculty of education or who holds a Ph.D. It should not be ignored that an academic staff made up predominantly of faculties of theology or arts and sciences graduates will suffer from certain limitations to their abilities in training Arabic language teachers.

\section{References}

Akdemir, A. S. (2013). Türkiye'de öğretmen yetiştirme programlarının tarihçesi ve sorunları. Turkish Studies- International Periodical For The Languages, Literature and History of Turkish or Turkic, $8 / 12,15-28$. 
Akyüz, Y. (2006). Türkiye'de öğretmen yetiştirmenin 160. Yılında Darülmuallin'in ilk yıllarına toplu ve yeni bir bakış. Ankara Üniversitesi Osmanlı Tarihi Araştırma ve Uygulama Merkezi Dergisi, 20, 17-58.

Demirel, Ö. (1991). Türkiye'de yabancı dil öğretmeni yetiştirmede karşılaşılan güçlükler. Hacettepe Üniversitesi Eğitim Fakültesi Dergisi, 6, 25-39.

Ev, H. (2011). Türkiye'de öğretmen yetiştirme sistemi ve din öğretimi alanına öğretmen yetiştirme. Dokuz Eylül Üniversitesi İlahiyat Fakültesi Dergisi, 9-50.

Gömleksiz, M. N. (1999). Yabancı dil öğretmenlerinin yetiştirilmesi sorunlar ve çözüm önerileri. Fırat Üniversitesi Sosyal Bilimler Dergisi, 9, 79-101.

Irgatoğlu, A. (2018). The current system of teacher training programs in one-year preparatory school of foundation universities in Ankara. Curr Res Educ, 4(1), 20-35

Komisyon, (2017). Öğretmen mesleki genel yeterlikleri. Millı̂ Eğitim Bakanlığı.

Özcan, M . (2015). Yabancı Dil Olarak Arapça Konuşma Becerisi Öğretiminde İletişimsel Yaklaşıma Dayalı Etkinliklerin Kullanımı. 21. Yüzyılda Eğitim ve Toplum Eğitim Bilimleri ve Sosyal Araştırmalar Dergisi , 4(10), 153-164 .

Soyupek, H. (2004). II. Meşrutiyetten günümüze Türkiye'de Arapça öğretimi. Süleyman Demirel Üniversitesi, Sosyal Bilimler Enstitüsü, Yayımlanmamış doktora tezi.

Abdul Hamid, M.F, Ab. Halim, Z., Sahrir, M.S. (2020). An insight on needs analysis towards the development of animated infographic module in arabic grammar learning. Journal of Language and Linguistic Studies, 16(3), 1387-1401. Doi: 10.17263/jlls.803813

\section{AUTHOR BIODATA}

Gürkan Dağbaşı works as an associate professor at the School of Foreign Languages of Ankara Hacı Bayram Veli University. He is also working there as vice president. He is a graduate of the Arabic Language Teaching Department of Gazi University. He completed his MA and Ph.D. at the same department of Gazi University. He worked at Çankırı University. His interest areas are language teaching and translation studies. 